Kyoto University,

Graduate School of Economics

Discussion Paper Series

Foreign Direct Investment and Temporary Workers in Japan

Ayumu TANAKA

Discussion Paper No. E-16-011

Graduate School of Economics

Kyoto University

Yoshida-Hommachi, Sakyo-ku

Kyoto City, 606-8501, Japan

December, 2016 


\title{
Foreign Direct Investment and Temporary Workers in Japan
}

\author{
Ayumu Tanaka*†
}

December 6, 2016

\begin{abstract}
The rapid growth in the number of temporary workers in Japan during the 2000s generated greater income inequality and greater job insecurity because temporary workers' wages are lower and their jobs are more tenuous than those of permanent workers. However, little is established about the relation between globalization and domestic growth in the temporary workforce. This study examines that relationship. It investigates whether the initiation of foreign direct investment (FDI) into Asia increased temporary workers' share of total wages and employment. This study employs a first-differenced difference-indifference estimation with propensity score matching to examine how the initiation of FDI among Japanese manufacturers during 2003-2004 affected domestic employment. Firmlevel data cover the period following the 2004 deregulation, which accelerated increases in the number of temporary workers by allowing manufacturers to employ such workers indirectly through employment agencies. Positive effects of vertical FDI are observed on the temporary worker ratio one year after starting FDI, but vanish in subsequent years. Therefore, this study concludes that the relationship between temporary workers and offshoring is complementary in the early stage of FDI and that no persistent effect of offshoring occurs that results in greater income inequality and greater job insecurity through an increase in the number of temporary workers.
\end{abstract}

Keywords: foreign direct investment; difference-in-difference estimation; propensity score matching; temporary workers

JEL Classification: F16, F21, F23

\footnotetext{
* Research Fellow, Research Project Center, Graduate School of Economics, Kyoto University

${ }^{\dagger}$ Associate Professor, Faculty of Commerce, Chuo University. Tel: +81-42-674-3511. E-mail: atanaka@tamacc.chuo-u.ac.jp. Address: 742-1 Higashinakano Hachioji-shi, Tokyo 192-0393 Japan.
} 


\section{Introduction}

Temporary workers have become increasingly important in developed economies such as Germany, Spain, France, and Japan. Facing global competition from low-wage countries, firms in developed economies seek to reduce costs, including labor costs. Hiring temporary workers is one strategy for reducing labor costs. Another strategy is offshoring, i.e., relocating business processes to other countries.

The hypothesis that hiring temporary workers is a substitute for offshoring is examined in a previous study (Presbitero et all, 2015). In practice, however, firms can employ both strategies simultaneously because offshoring might not prevent firms from hiring temporary domestic workers. Therefore, this study re-examines this hypothesis using Japanese firm-level data. In particular, this study investigates whether firms that initiate vertical foreign direct investment (FDI) tend to increase the employment and wage share of temporary workers. To address potential endogeneity issues, this study employs first-differenced difference-indifference (DID) estimators. In addition, this study conducts DID estimation using a matched sample. The matching is conducted using the propensity score matching (PSM) technique. $\rrbracket^{-}$

The estimation results indicate that one year after starting FDI, vertical FDI raises the share of temporary workers in the total wage bill and in total employment. These results suggest that vertical FDI and temporary workers are complements rather than substitutes during the early stages of FDI. However, the results show that the complementary relationship between temporary workers and vertical FDI is not persistent because the positive effects on the temporary worker ratio vanish two years after starting FDI.

This study is divided into eight sections, including this section. Section 2 explains the background. Section 3 describes the data, variables, and descriptive statistics of the data. Section 4 introduces the empirical strategy. Section 5 reports benchmark results of the simple DID estimation using the unmatched sample. Section 6 presents the estimation results of firms' decisions to initiate vertical FDI and the results of DID using the matched sample. Section 7 provides the robustness checks. Section 8 summarizes and concludes the study.

\section{Background}

Employing temporary workers ${ }^{20}$ is one of the major strategies used by firms to reduce labor costs because wages and hiring and firing costs for temporary workers are lower than those for permanent workers. Temporary workers receive lower average wages and benefits than

\footnotetext{
${ }^{* 1}$ Crinò (20II) also employed the PSM technique to examine the effects of offshoring on the skill composition of employment.

${ }^{*} 2$ The distinction between temporary and permanent workers resembles the traditional distinction between unskilled and skilled workers because temporary workers are generally less skilled than permanent workers. College-educated workers are less likely to work as temporary workers (Asano et al., 2013), indicating that temporary workers are less educated than permanent workers.
} 
permanent workers and enjoy less stable employment (Esteban-Pretel et al, 2017). They are widely denied access to training, possibility for promotion, and eligibility to unionize.

In Japan, the share of temporary workers ${ }^{[3}$ rose during the 2000s. In 2004, deregulation accelerated their rising numbers by enabling manufacturers to employ temporary workers indirectly through employment services ("dispatched workers"). the wages and employment of temporary workers in Japan's machinery industry during 20012013. The former shows their share of wages as a percentage of total wages paid (wage share); the latter shows their employment as a percentage of total employment (employment share). The wage share $(T E M P S)$ is defined as

$$
T E M P S=\frac{\text { Wage cost for temporary workers }}{\text { Total wage bill }} \times 100
$$

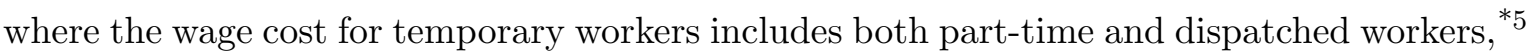
and total wage bill includes both temporary and permanent workers.

The employment share of temporary workers $(T E M P R)$ is defined as follows:

$$
T E M P R=\frac{\text { Temporary workers }}{\text { Temporary workers }+ \text { Permanent workers }} \times 100
$$

where

$$
\begin{aligned}
\text { Temporary workers }=\quad & \text { Part-time workers }+ \text { Dispatched workers } \\
& + \text { Day laborers }
\end{aligned}
$$

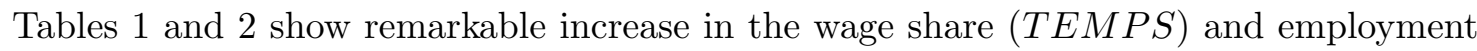
share (TEMPR) of temporary workers. Their wage share rose from $2.4 \%$ to $8.7 \%$ and their employment share rose from $7.7 \%$ to $17.0 \%$ between 2001 and 2007 . Among temporary workers, dispatched workers represented significantly increasing percentages of the wage share and employment share (DISPS and DISPR) between 2001 and 2007. However, shares for part-time workers ( $P A R T S$ and $P A R T S)$ and day laborers $(D A Y R)$ remained nearly stable during this period. On the flip side, Tables $\square$ and $\nabla$ show that permanent workers accounted for a declining share of wages (from $97.6 \%$ to $91.3 \%$ ) and employment (from $92.3 \%$ to $83.0 \%$ ) during that period. In sum, between 2001 and 2007, Japanese manufacturers rapidly increased their employment of temporary workers, particularly dispatched workers, as reflected by the total wages and employment.

The 2008 world financial crisis largely affected the increasing trend of temporary workers.

\footnotetext{
${ }^{*} 3$ Temporary workers are called "non-standard workers" in Japan.

${ }^{*} 4$ The Japanese government permitted worker dispatching only in very limited cases until 1999 but it gradually removed the restrictions on worker dispatching from the late 1990s to the early 2000s (Okudaira et al., [2013). The 2004 deregulation is important since it allowed worker dispatching in manufacturing industries.

${ }^{*}$ Wage cost for day laborers is unavailable and therefore excluded.
} 
Table $\rrbracket$ shows that the employment of temporary workers declined from $17.0 \%$ to $11.2 \%$ between 2007 and 2008 and the employment of dispatched workers declined from $12.4 \%$ to $6.9 \%$. These findings indicate that around 0.2 million dispatched workers lost their jobs. After 2008, the employment of temporary workers did not recover to pre-crisis levels.

Table 1: Wage share of temporary workers in Japanese machinery industry (2001-2013)

\begin{tabular}{lrrrrr}
\hline year & $\begin{array}{r}\text { WB } \\
\text { (trillion) }\end{array}$ & $\begin{array}{r}\text { PERMS } \\
\mathbf{( \% )}\end{array}$ & $\begin{array}{r}\text { TEMPS } \\
\mathbf{( \% )}\end{array}$ & $\begin{array}{r}\text { DISPS } \\
\mathbf{( \% )}\end{array}$ & $\begin{array}{r}\text { PARTS } \\
\mathbf{( \% )}\end{array}$ \\
\hline 2001 & 17.6 & 97.6 & 2.4 & 1.7 & 0.7 \\
2002 & 16.8 & 96.9 & 3.1 & 2.3 & 0.8 \\
2003 & 17.7 & 96.4 & 3.6 & 2.8 & 0.8 \\
2004 & 18.0 & 95.4 & 4.6 & 3.8 & 0.8 \\
2005 & 17.6 & 94.2 & 5.8 & 4.9 & 0.9 \\
2006 & 16.8 & 92.0 & 8.0 & 6.9 & 1.1 \\
2007 & 18.1 & 91.3 & 8.7 & 7.7 & 1.0 \\
2008 & 16.3 & 94.6 & 5.4 & 4.4 & 1.0 \\
2009 & 15.2 & 95.3 & 4.7 & 3.7 & 1.1 \\
2010 & 15.6 & 95.2 & 4.8 & 3.6 & 1.2 \\
2011 & 15.9 & 95.0 & 5.0 & 3.8 & 1.3 \\
2012 & 16.0 & 95.7 & 4.3 & 3.2 & 1.1 \\
2013 & 16.1 & 95.6 & 4.4 & 3.4 & 1.1
\end{tabular}

Notes: Calculations are from the panel data of Japanese firms for 2001-2013 constructed from the Basic Survey of Japanese Business Structure and Activities by the Japanese Ministry of Economy, Trade and Industry. $W B$ denotes total wages in trillion yen in Japan's machinery industry. PERMS denotes permanent workers' share of total wages. TEMPS denotes temporary workers' share of total wages.

DISPS and PARTS are the wage shares of dispatched and part-time workers, respectively.

During the sample period, Japanese firms also increased vertical FDI or offshoring. Although offshoring enables firms to employ workers in low-wage countries, whether offshoring substitutes for employing temporary workers is a less explored question. Using firm-level data from Italian manufacturers, Presbitero et al. (2015) examined whether the employment share of temporary workers affects offshoring. They found that firms with higher ratios of temporary workers exhibit reduced tendencies to offshore but that this relationship vanishes after controlling for endogeneity.

This study uses Japanese firm-level data to examine the relationship between offshoring and employing temporary workers. It particularly investigates the causal effects of vertical FDI on wage and employment shares of temporary workers. To do so, it employs FDI in Asia as a measure of offshoring.

\section{Data}

This study employs Japanese firm-level data to examine whether vertical FDI substitutes for employing temporary workers. The data are from the Basic Survey of Japanese Business Structure and Activities by the Japanese Ministry of Economy, Trade and Industry (METI survey). The METI survey covers Japan's manufacturing and non-manufacturing industries, 
Table 2: Employment share of temporary workers in Japan's machinery industry (2001-2013)

\begin{tabular}{lrrrrrr}
\hline year & $\begin{array}{r}\mathbf{N} \\
\text { (million) }\end{array}$ & $\begin{array}{r}\text { PERMR } \\
\mathbf{( \% )}\end{array}$ & $\begin{array}{r}\text { TEMPR } \\
\mathbf{( \% )}\end{array}$ & $\begin{array}{r}\text { DISPR } \\
\mathbf{( \% )}\end{array}$ & $\begin{array}{r}\text { PARTR } \\
\mathbf{( \% )}\end{array}$ & $\begin{array}{r}\text { DAYR } \\
\mathbf{( \% )}\end{array}$ \\
\hline 2001 & 2.6 & 92.3 & 7.7 & 3.5 & 3.6 & 0.7 \\
2002 & 2.6 & 91.1 & 8.9 & 4.7 & 3.5 & 0.6 \\
2003 & 2.7 & 90.1 & 9.9 & 5.7 & 3.5 & 0.7 \\
2004 & 2.8 & 88.6 & 11.4 & 7.4 & 3.4 & 0.7 \\
2005 & 2.8 & 86.7 & 13.3 & 9.1 & 3.7 & 0.6 \\
2006 & 3.0 & 84.0 & 16.0 & 11.2 & 4.2 & 0.7 \\
2007 & 3.2 & 83.0 & 17.0 & 12.4 & 3.9 & 0.7 \\
2008 & 3.0 & 88.8 & 11.2 & 6.9 & 3.9 & 0.4 \\
2009 & 2.9 & 90.0 & 10.0 & 5.6 & 3.9 & 0.6 \\
2010 & 2.9 & 89.4 & 10.6 & 5.6 & 4.3 & 0.7 \\
2011 & 2.9 & 88.9 & 11.1 & 5.8 & 4.5 & 0.7 \\
2012 & 2.8 & 90.2 & 9.8 & 4.9 & 4.1 & 0.8 \\
2013 & 2.8 & 90.1 & 9.9 & 5.3 & 4.0 & 0.6 \\
\hline
\end{tabular}

Notes: Calculations are from panel data of Japanese firms for 2001-2013 constructed from the Basic Survey of Japanese Business Structure and Activities by the Japanese Ministry of Economy, Trade and Industry. $N$ indicates the total of all workers in Japan's machinery industry. PERMR is the ratio of permanent workers to all workers. TEMPR is the ratio of temporary workers to all workers. DISPR, PARTS, DAYR are the wage shares of dispatched workers, part-time workers, and day laborers, respectively.

but this study focuses on four sectors of Japan's machinery industry noted for vertical FDI.

Subjects of the METI survey are firms with more than 50 employees and more than 30 million yen in capital. Although the survey excludes small firms, it is the most comprehensive one available for purposes of this study.

Following Hijzen et aI. (2010), I construct a two-year panel of the cohort of FDI starters and non-starters (non-MNEs) among panel data for Japanese firms for 2001-2007, as illustrated in Table 3. This study uses the data for the period 2001-2007 for two reasons. First, this period includes the year of deregulation of dispatched workers in manufacturing industries. The 2004 deregulation has accelerated employment of temporary workers by allowing manufacturing firms to indirectly employ dispatched workers. Second, this period has less macroeconomic shocks since it excludes the 2008 financial crisis, which occasioned swift declines in the employment of temporary workers. As explained in the previous section, the 2008 financial crisis has changed the increasing trend of temporary workers in Japan. This study, therefore, focuses on the pre-crisis period in the main analysis but also conducts the analysis using the data for the period 2003-2013 in Section 7.3.

Cohorts are defined as six-year windows, $[t-2, t+3]$, where $t$ is the year in which nonMNEs could initiate FDI. In my data, the switch year $t$ is within the range [2003,2004]. I imposed the condition that the panel be balanced within a six-year window.

The METI survey asks whether the responding firms have subsidiaries in Asia, North America, Europe, or elsewhere. Utilizing this information, firms with no foreign subsidiary

\footnotetext{
${ }^{* 6}$ See Nishimura et al. (2005) and Kimura and Kiyota (2006) for more details about the METI survey.
} 
Table 3: Cohort of FDI initiators and non-MNEs

\begin{tabular}{ccc}
\hline & Cohort 1 & Cohort 2 \\
& Start year $=\mathbf{2 0 0 3}$ & Start year $=\mathbf{2 0 0 4}$ \\
\hline$t-2$ & 2001 & 2002 \\
$t-1$ & 2002 & 2003 \\
$t$ & $\mathbf{2 0 0 3}$ & $\mathbf{2 0 0 4}$ \\
$t+1$ & 2004 & 2005 \\
$t+2$ & 2005 & 2006 \\
$t+3$ & 2006 & 2007 \\
\hline
\end{tabular}

are classified as non-MNEs and firms with a foreign subsidiary are considered MNEs. This study regards Japanese firms with foreign subsidiaries in Asia as firms that conduct vertical FDI.

Table 4 reports the total number of non-MNEs, FDI initiators in Asia, and MNEs in the data. FDI initiators are firms that initiated FDI in Asia between 2003 and 2004 and retained the subsidiaries for three subsequent years. Non-MNEs had no foreign subsidiaries during any of the six sampled years, $[t-2, t+3]$. MNEs had foreign subsidiaries throughout all six years.

Among 94 FDI initiators, 68 initiate FDI only in Asia. To estimate the precise effects of vertical FDI, I exclude firms that initiate FDI in multiple regions and outside Asia. I also exclude MNEs and other firms and distill the sample to non-MNEs and FDI initiators in Asia for the DID estimation.

Table 4: Firm type by industry

\begin{tabular}{lrrrrr}
\hline Industry & Non-MNE & FDI initiator & MNE & Other & Total \\
\hline machinery and equipment & 1,244 & 25 & 479 & 183 & 1,931 \\
electrical machinery and apparatus & 1,636 & 19 & 577 & 202 & 2,434 \\
motor vehicles & 859 & 20 & 384 & 149 & 1,412 \\
precision instruments & 269 & 4 & 92 & 49 & 414 \\
Total & 4,008 & 68 & 1,532 & 583 & 6,191 \\
\hline
\end{tabular}

Notes: Numbers of firms are based on the three-year panel cohort of treated and control firms from panel data of Japanese firms for 2001-2007. "FDI initiators" are firms that initiated vertical FDI during 2003-2004. "Non-MNEs" had no foreign subsidiaries during all six years, $[t-2, t+3]$, whereas "MNEs" had foreign subsidiaries during all six years. Firms that initiated FDI but closed their foreign subsidiaries are included in "Other." Firms that initiated FDI outside Asia are also included in "Other."

The METI survey lacks wage data for temporary workers. This study, therefore, accesses data from other governmental statistics. In particular, the METI survey sums the wages for permanent and part-time workers. To isolate wages for permanent workers, I calculate firm-level totals for part-time workers using information about industry-level average hourly wages and hours worked from Monthly Labor Survey by the Ministry of Health, Labour and Welfare. In addition, I calculate firm-level wage totals for dispatched workers, using data 
from the Ministry of Health, Labour and Welfare's General Survey on Dispatched Workers and Report on the Activity of Temporary Help Agency.

\section{Empirical strategy: Difference-in-difference estimation}

To address endogeneity from unobserved firm characteristics affecting the ratio of temporary workers and the decision to initiate FDI, I employ a first-differenced DID estimator for both unmatched and matched samples. To conduct DID estimation, I utilize the differences in FDI status and time periods.

First, I distinguish the post-treatment period from the pre-treatment period. For the case in which the FDI starting year is 2003, the pre-treatment period is 2001-2002, whereas the post-treatment period is 2004-2006. Similarly, when the FDI starting year is 2004, the pretreatment period is 2002-2003, whereas the post-treatment period is 2005-2007. Therefore, sampled firms cannot employ "dispatched workers" during the pre-treatment periods but can do so during the post-treatment period following the 2004 deregulation. Second, I distinguish FDI initiators as the treatment group from non-MNEs as the control group.

Berman et al. (1998) and many previous studies employ the translog cost function to analyze demand for skilled workers because it allows for cross-factor substitution or complementarity and heterothetic production. As discussed in Head and Ries (20102), the share of some variable factor in variable costs can be expressed as a linear function of the logs of input prices and quasi-fixed factors when the translog cost function is employed.

Following Berman et al. (1998) and Head and Ries (20102), I employ the translog cost function and interpreted capital as a quasi-fixed and predetermined factor affecting labor costs. Therefore, the wage share of temporary workers (TEMPS) can be expressed as follows:

$$
\begin{aligned}
T E M P S_{i}= & \alpha_{0}+\alpha_{1} M N E_{i}+\alpha_{2} \ln W A G E_{i} \\
& +\alpha_{3} \ln C I_{i}+\alpha_{4} \ln V A_{i} \\
& +\alpha_{5} \ln W A G E_{T E M P, i}+\text { INDUSTRY }
\end{aligned}
$$

where $V A$ is value added and $C I$ is the measure of capital intensity, defined as capital over value added, as in Head and Ries (2002). The subscript $i$ indexes the firm. WAGE is the firmlevel hourly wage of permanent workers. Firm-level temporary workers' wages, $W A G E_{T E M P}$, are unavailable and assumed to exhibit no exogenous variation across industries. Therefore, this variable is omitted in the empirical analysis, as in Head and Ries (2012). Instead, the industry fixed effect, INDUSTRY, is included. An indicator variable for multinational enterprises in Asia $(M N E)$ is included to examine relationships between offshoring and the increased use of temporary workers. 
After first-differencing the previous equation, I estimate this equation:

$$
\begin{aligned}
\mathrm{d} T E M P S_{i, t+s} & =\beta_{1} F D I_{-} S T A R T_{i}+\beta_{2} \mathrm{~d} \ln W A G E_{i, t+s} \\
& +\beta_{3} \mathrm{~d} \ln C I_{i, t+s}+\beta_{4} \mathrm{~d} \ln V A_{i, t+s} \\
& +\mathrm{d} I N D U S T R Y_{i, t+s}+Y E A R_{i, t}+\varepsilon
\end{aligned}
$$

where FDI_START is the DID dummy that identifies FDI initiators. Subscripts $t$ and $s$ indicate the year in which a firm initiated FDI and the number of years after $t$, respectively.

The dependent and explanatory variables are defined as $\mathrm{d} V A R_{i, t+s}=V A R_{i, t+s}-V A R_{i, t-2}$. For example, dTEMP $S_{i, t+3}$ is defined as TEMPS $S_{i, t+3}-T E M P S_{i, t-2}$. Similarly, dlnTEMPS $S_{i, t+2}$ is defined as $\ln T E M P S_{i, t+2}-\ln T E M P S_{i, t-2}$. $\mathrm{d} I N D U S T R Y$ is an indicator variable that takes the value of one if a firm switched industries between $t-2$ and $t+s$. YEAR is the switch-year fixed effects to control for the year during which a firm initiated FDI. The empirical analysis adopts the temporary worker ratio $(T E M P R)$ as an alternative dependent variable alongside the wage share of temporary workers (TEMPS).

\section{DID estimation using an unmatched sample}

This section presents the DID estimation results using an unmatched sample. Table 5 shows the results. Columns (1)-(3) show estimation results using the wage share of temporary workers (TEMPS) as a dependent variable. Columns (4)-(6) show estimation results using the employment share of temporary workers $(T E M P R)$ as a dependent variable. Coefficients of the DID dummy, FDI_START, are positive and significant in columns (1) and (4). This result indicates that one year after initiating FDI in Asia, firms increase their shares of temporary workers more than do non-MNEs. This finding suggests that vertical FDI and employing temporary workers are complements rather than substitutes during the early stages of FDI. It may be that firms increase their proportions of temporary workers rather than permanent workers because they might use temporary workers to buffer foreign demand shocks. ${ }^{[7}$ In addition, finding permanent workers immediately after initiating FDI in a frictional labor market might be difficult.

However, the results also indicate that the complementary relationship between temporary workers and vertical FDI vanishes two years after initiating FDI. Therefore, vertical FDI does not result in widening income inequality through an increase in the share of temporary workers.

The coefficients of dn $W A G E$ are negative and significant in columns (1)-(3) but positive in columns (4)-(6) and significant in column (5). These results indicate that firms experiencing higher growth in the hourly wages of permanent workers reduce the wage share but

\footnotetext{
${ }^{*}$ [Asano et al. (2013) point out that demand shock, as measured by uncertain sales growth, is a significant determinant of the Japanese firms' decision to hire temporary workers.
} 
increase the employment share of temporary workers.

The coefficients of capital intensity growth $(\operatorname{dln} C I)$ are positive and significant in columns (1)-(3), suggesting that firms with higher capital-intensity growth increase the wage share of temporary workers. The coefficients of value-added growth $(\operatorname{dn} V A)$ are positive and significant in column (6) but insignificant in columns (1)-(5). The coefficients of $\mathrm{d} I N D U S T R Y$ are positive and significant in column (3) but insignificant in most columns.

To summarize, the estimation results using the unmatched sample indicate that vertical FDI and temporary workers are complements rather than substitutes during the initial stages of FDI. However, complementarity between offshoring and temporary workers disappears in subsequent years. Therefore, this section finds little evidence that vertical FDI raises income inequality through an increase in the share of temporary workers.

Table 5: Effects of FDI in Asia on the ratio of temporary workers: DID using the unmatched sample

\begin{tabular}{|c|c|c|c|c|c|c|}
\hline & $(1)$ & $\begin{array}{c}(2) \\
\text { dTEMPS }\end{array}$ & (3) & (4) & $\begin{array}{c}(5) \\
\text { dTEMPP }\end{array}$ & (6) \\
\hline & $t+1$ & $\mathrm{t}+2$ & $t+3$ & $t+1$ & $t+2$ & $t+3$ \\
\hline FDI_START & $\begin{array}{c}1.767^{* *} \\
{[0.853]}\end{array}$ & $\begin{array}{c}1.010 \\
{[1.002]}\end{array}$ & $\begin{array}{l}-0.077 \\
{[1.235]}\end{array}$ & $\begin{array}{c}2.799^{* *} \\
{[1.184]}\end{array}$ & $\begin{array}{c}1.449 \\
{[1.415]}\end{array}$ & $\begin{array}{c}0.883 \\
{[1.660]}\end{array}$ \\
\hline dlnWAGE & $\begin{array}{c}-1.750 * * * \\
{[0.442]}\end{array}$ & $\begin{array}{c}-1.928^{* *} \\
{[0.850]}\end{array}$ & $\begin{array}{c}-2.328^{* *} \\
{[0.974]}\end{array}$ & $\begin{array}{c}0.221 \\
{[0.519]}\end{array}$ & $\begin{array}{c}1.455^{* *} \\
{[0.729]}\end{array}$ & $\begin{array}{c}0.688 \\
{[0.762]}\end{array}$ \\
\hline $\mathrm{d} \operatorname{lnCI}$ & $\begin{array}{c}3.093^{* * *} \\
{[0.748]}\end{array}$ & $\begin{array}{c}2.814^{* * *} \\
{[0.764]}\end{array}$ & $\begin{array}{c}3.138^{* * *} \\
{[0.882]}\end{array}$ & $\begin{array}{c}0.572 \\
{[0.774]}\end{array}$ & $\begin{array}{c}0.756 \\
{[0.826]}\end{array}$ & $\begin{array}{c}0.859 \\
{[0.881]}\end{array}$ \\
\hline$d \ln V A$ & $\begin{array}{l}-0.226 \\
{[0.371]}\end{array}$ & $\begin{array}{c}0.328 \\
{[0.392]}\end{array}$ & $\begin{array}{c}0.577 \\
{[0.545]}\end{array}$ & $\begin{array}{c}0.721 \\
{[0.467]}\end{array}$ & $\begin{array}{c}0.470 \\
{[0.453]}\end{array}$ & $\begin{array}{c}1.435^{* * *} \\
{[0.470]}\end{array}$ \\
\hline dINDUSTRY & $\begin{array}{c}0.375 \\
{[0.585]}\end{array}$ & $\begin{array}{c}0.729 \\
{[0.641]}\end{array}$ & $\begin{array}{l}1.184^{*} \\
{[0.650]}\end{array}$ & $\begin{array}{l}-0.074 \\
{[0.813]}\end{array}$ & $\begin{array}{c}0.468 \\
{[0.871]}\end{array}$ & $\begin{array}{c}1.293 \\
{[0.842]}\end{array}$ \\
\hline Observations & 4076 & 4076 & 4076 & 4076 & 4076 & 4076 \\
\hline $\mathrm{R}$-squared & 0.031 & 0.021 & 0.025 & 0.003 & 0.007 & 0.008 \\
\hline
\end{tabular}

Notes: Standard errors are in brackets. Constants are suppressed. ${ }^{* *},{ }^{* *}$, and $*$ indicate significance at $1 \%$, $5 \%$, and $10 \%$, respectively.

\section{DID estimation using a matched sample}

\subsection{Decision to initiate FDI}

This section concerns DID estimation using the matched sample. To construct the control group, I estimate the propensity score to initiate FDI using a sample of non-MNEs and FDI 
initiators in Asia:

$$
\begin{aligned}
P\left(D_{i t}=1\right)= & F\left(\ln T F P_{i, p r e}, \ln K L_{i, p r e}, \ln W A G E_{i, p r e},\right. \\
& R D I N T_{i, p r e}, E X P O R T I N T_{i, p r e}, \ln A G E_{i, p r e}, \\
& \left.F O R_{i, p r e}, \ln S A L E S_{i, t-2}, Y E A R_{i, t}, I_{N D U S T R} Y_{i, t-2}\right),
\end{aligned}
$$

where $F$ is a logistic cumulative distribution function. TFP, KL, WAGE, RDINT, EXPORTINT, $A G E, F O R$, and $S A L E S$ indicate the total factor productivity (TFP) ${ }^{\otimes}$, the capital-labor ratio, permanent workers' hourly wage, $\mathrm{R} \& \mathrm{D}$ intensity (R\&D-sales ratio), export intensity (export-sales ratio), firm age, foreign ownership ratio, and sales, respectively. I include these explanatory variables with a two-year lag, following previous studies such as Hijzen et al. (सणI). This lag is used because explanatory variables with a one-year lag might capture some anticipatory effects of the FDI decision affecting the observable characteristics of the firm when the decision to invest is made one or two years before the investment is made. The year and industry fixed effects (YEAR and INDUSTRY) are also included.

Table [ shows the estimation results of equation (6). The coefficient of $\ln S A L E S$ is significant and positive, indicating that larger firms are more likely to initiate FDI in Asia, as predicted by a standard firm heterogeneity model such as that in Helpman et al. (20104). However, the coefficient of $\ln T F P$ is insignificant. This insignificance can be explained by the fact that this study focuses on vertical FDI rather than horizontal FDI. The cutoff productivity for FDI in Asia might be low enough because the wage level is much lower in other Asian countries than in Japan.

The coefficient of RDINT is significant and positive, suggesting that $\mathrm{R} \& \mathrm{D}$-intensive firms are more likely to initiate FDI in Asia. This tendency might indicate the importance of firm-level scale economies. All other variables, including $K L, W A G E, A G E, F O R$, and EXPORTINT, are insignificant.

Using the estimated probability to start the first FDI in Asia, the firms are matched using the one-to-one nearest matching method with replacement. The non-MNE $c(i)$ with the closest propensity score to start FDI in Asia is selected for each FDI starter $i$, as follows:

$$
c(i)=\min _{j \in\left\{D_{j t}=0\right\}}\left\|\hat{P_{i t}}-\hat{P_{j t}}\right\| .
$$

Firms are matched separately for each starting year $(t)$, each two-digit industry, and export status. Based on the matching, the matched sample is constructed for the DID estimation.

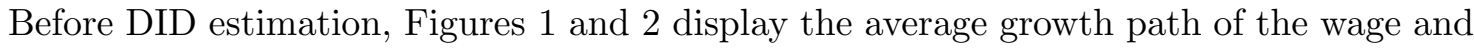

\footnotetext{
${ }^{*} \mathrm{TFP}$ is calculated from an estimated two-digit industry-specific production function, using Levinsohn and Petrin (2003) techniques. Japanese parent firms' real value added is the output, whereas numbers of permanent and temporary workers, fixed tangible assets, and intermediate inputs are inputs. Transportation and packaging costs are used to proxy unobserved productivity shocks because my data contain no costs for electricity or fuels.
} 
Table 6: Decision to initiate FDI in Asia

\begin{tabular}{lc}
\hline \hline & Initiating FDI in Asia \\
\hline lnTFP_pre & -0.052 \\
& {$[0.310]$} \\
lnKL_pre & -0.049 \\
& {$[0.115]$} \\
lnWAGE_pre & -0.174 \\
& {$[0.153]$} \\
RDINT_pre & $6.232^{* * *}$ \\
& {$[2.144]$} \\
EXPORTINT_pre & 1.069 \\
& {$[0.792]$} \\
lnAGE_pre & 0.363 \\
& {$[0.267]$} \\
FOR_pre & -0.002 \\
pseudo-R-squared & {$[0.010]$} \\
\hline \hline
\end{tabular}

Notes: Standard errors are in brackets. The constants, year, and industry fixed effects are suppressed. ***, $* *$, and $*$ indicate significance at $1 \%, 5 \%$, and $10 \%$, respectively.
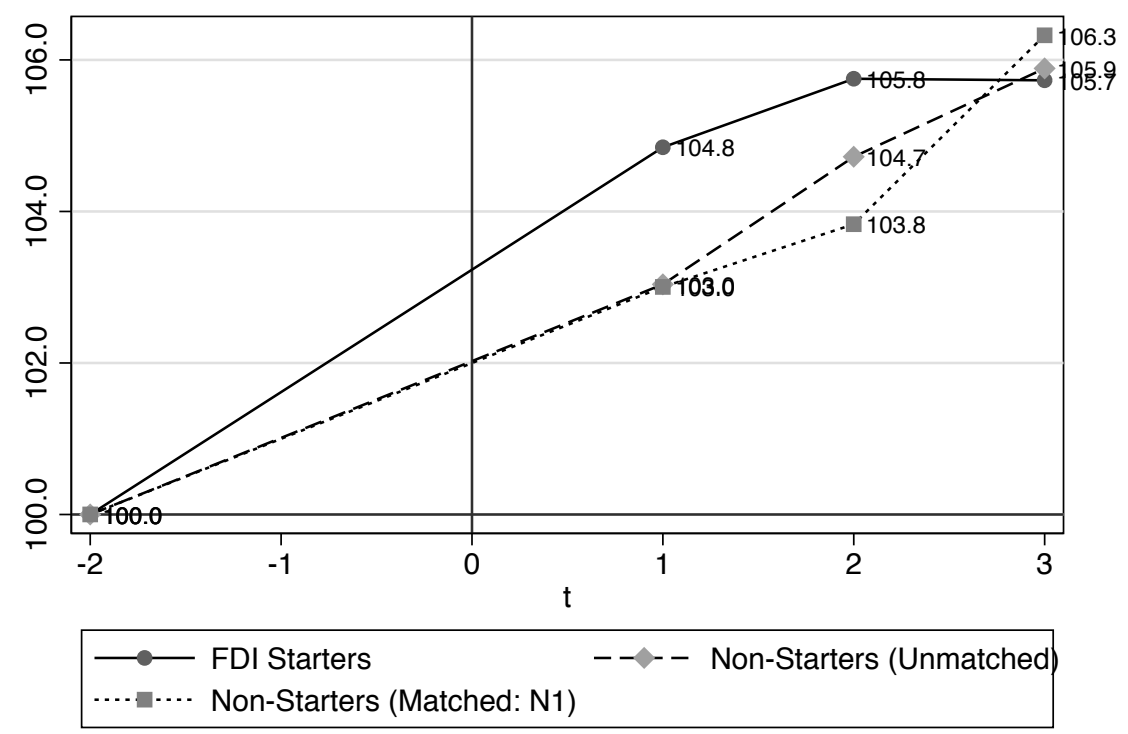

Figure 1: Impacts of FDI in Asia on the wage share of temporary workers (TEMPS) 


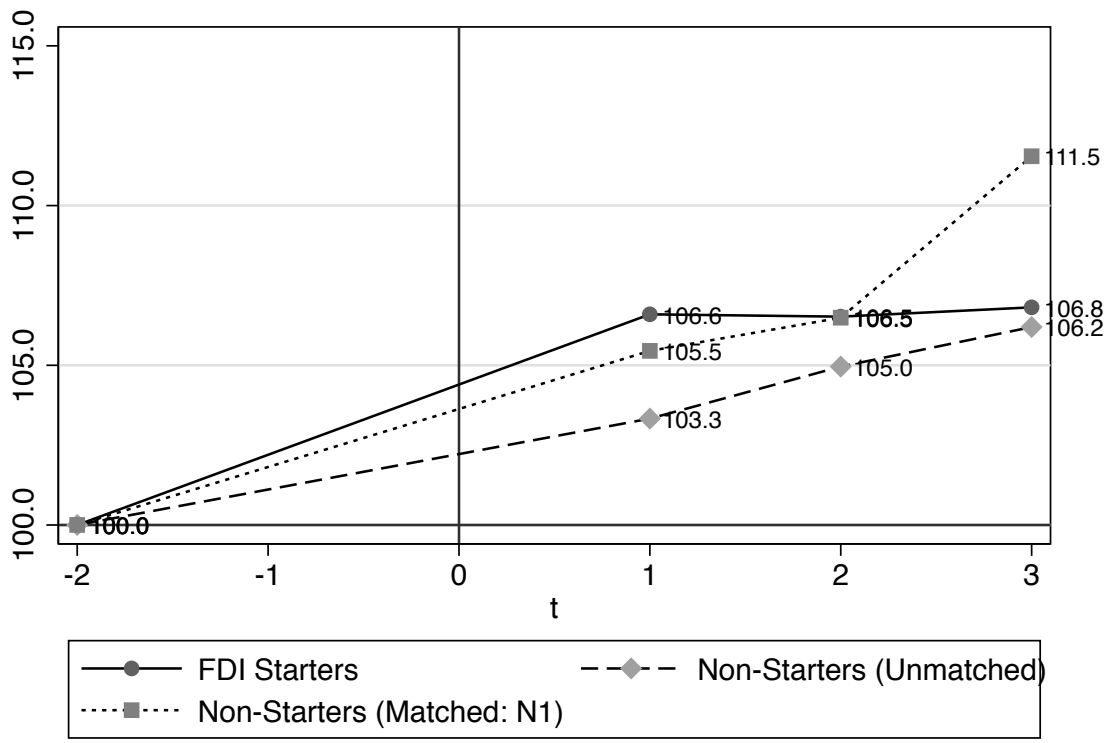

Figure 2: Impacts of FDI in Asia on employment share of temporary workers (TEMPR)

employment shares, respectively, of temporary workers. The solid line represents firms that initiate FDI in Asia and the broken lines represent the non-MNEs. Short and long broken lines represent results from using matched and unmatched firms, respectively. Figure $\square$ shows that FDI initiators in Asia, on average, increase the wage share of temporary workers after initiating FDI; as for growth in that share, however, differences between FDI initiators and non-MNEs vanish in the following years. Figure $\rrbracket$ shows that FDI initiators' average growth in the share of temporary workers slightly exceeds that of non-MNEs one year after initiating FDI but becomes similar or lower thereafter.

\subsection{Comparison between FDI initiators and non-MNEs}

This subsection provides descriptive statistics for comparing FDI initiators and non-MNEs using the unmatched and matched samples. Table $\square$ examines whether FDI initiators, on average, increase the number of permanent workers (PERM) and temporary workers (TEMP) more than non-MNEs using both unmatched and matched samples. It shows that the FDI initiators, on average, increase the number of permanent workers more than both unmatched and matched non-MNEs. It also shows that FDI initiators, on average, increase the number of temporary workers more than unmatched non-MNEs but that the difference between FDI initiators and matched non-MNEs is not statistically significant.

Table $\mathbb{8}$ compares sales growth of FDI initiators and non-MNEs. FDI initiators increase both overall sales and export sales more than non-MNEs in the unmatched and matched 
Table 7: Comparison between FDI initiators and non-MNEs: Number of permanent and temporary workers

\begin{tabular}{|c|c|c|c|c|c|c|c|c|}
\hline & & Sample & Treated & Controls & Difference & S.E. & T-stat & \\
\hline \multirow{2}{*}{ dlnPERM } & $\mathrm{t}+1$ & Unmatched & 0.075 & 0.008 & 0.067 & 0.030 & 2.22 & $* *$ \\
\hline & & Matched & 0.075 & -0.045 & 0.120 & 0.054 & 2.22 & $* *$ \\
\hline \multirow[t]{2}{*}{ dlnPERM } & $\mathrm{t}+2$ & Unmatched & 0.144 & 0.022 & 0.122 & 0.034 & 3.56 & $* *$ \\
\hline & & Matched & 0.144 & -0.044 & 0.188 & 0.052 & 3.61 & $* *$ \\
\hline \multirow[t]{2}{*}{ dlnPERM } & $\mathrm{t}+3$ & Unmatched & 0.176 & 0.036 & 0.140 & 0.038 & 3.68 & $* *$ \\
\hline & & Matched & 0.176 & -0.061 & 0.237 & 0.045 & 5.25 & $* *$ \\
\hline \multirow[t]{2}{*}{ dlnTEMP } & $\mathrm{t}+1$ & Unmatched & 0.628 & 0.294 & 0.333 & 0.120 & 2.79 & $* *$ \\
\hline & & Matched & 0.628 & 0.516 & 0.112 & 0.314 & 0.36 & \\
\hline \multirow[t]{2}{*}{ dlnTEMP } & $\mathrm{t}+2$ & Unmatched & 0.688 & 0.431 & 0.257 & 0.132 & 1.94 & * \\
\hline & & Matched & 0.688 & 0.598 & 0.090 & 0.299 & 0.30 & \\
\hline \multirow[t]{2}{*}{ dlnTEMP } & $t+3$ & Unmatched & 0.770 & 0.529 & 0.241 & 0.141 & 1.72 & * \\
\hline & & Matched & 0.770 & 1.042 & -0.272 & 0.296 & -0.92 & \\
\hline
\end{tabular}

Notes: Treated and Controls denote the average for FDI starters and non-FDI starters, respectively. Treated and Controls are the change from $t-2$ in the log of variables. The number of treated firms is 56 . The common support condition is imposed. ${ }^{* *}$ and $*$ indicate significance at $5 \%$ and $10 \%$, respectively.

samples. The increase in export sales might explain the increase in permanent workers, given that exporting requires highly skilled workers.

\subsection{DID estimation using the matched sample}

Table 9 presents DID estimation results using the matched sample. The sample size is reduced to 112 due to matching. Columns (1)-(3) and columns (4)-(6) show estimation results using the wage share $(T E M P S)$ and employment share $(T E M P R)$ of temporary workers as dependent variables.

The results here again indicate that the coefficient of FDI_START is positive and significant one year after initiating FDI. That is, firms that initiate FDI increase the wage share and employment share of temporary workers. This result reinforces the previous finding that vertical FDI and temporary workers are complements during the early stages of FDI. The result again shows that the complementary relationship vanishes in subsequent years. This finding indicates that vertical FDI does not widen income inequality by increasing the ratio of temporary workers.

Several coefficients change signs given matching, which significantly attenuates differences in firm characteristics. The coefficients of $\operatorname{dn} W A G E$ turn positive in all columns and become significantly positive in columns (3)-(6). This finding indicates that firms that experience greater growth in permanent workers' hourly wages increase the wage and employment shares 
Table 8: Comparison between FDI initiators and non-MNEs: Overall sales and exports

\begin{tabular}{|c|c|c|c|c|c|c|c|c|}
\hline & & Sample & Treated & Controls & Difference & S.E. & T-stat & \\
\hline \multirow[t]{2}{*}{ dlnSALES } & $t+1$ & Unmatched & 0.487 & 0.363 & 0.124 & 0.052 & 2.37 & $* *$ \\
\hline & & Matched & 0.487 & 0.268 & 0.219 & 0.093 & 2.34 & $* *$ \\
\hline \multirow[t]{2}{*}{ dlnSALES } & $\mathrm{t}+2$ & Unmatched & 0.623 & 0.480 & 0.143 & 0.059 & 2.45 & $* *$ \\
\hline & & Matched & 0.623 & 0.265 & 0.358 & 0.095 & 3.78 & ** \\
\hline \multirow[t]{2}{*}{ dlnSALES } & $t+3$ & Unmatched & 0.715 & 0.582 & 0.133 & 0.066 & 2.03 & $* *$ \\
\hline & & Matched & 0.715 & 0.214 & 0.501 & 0.187 & 2.67 & $* *$ \\
\hline \multirow[t]{2}{*}{ dlnEXPORTS } & $\mathrm{t}+1$ & Unmatched & 1.289 & 0.243 & 1.046 & 0.177 & 5.90 & $* *$ \\
\hline & & Matched & 1.289 & 0.215 & 1.074 & 0.614 & 1.75 & * \\
\hline \multirow[t]{2}{*}{ dlnEXPORTS } & $\mathrm{t}+2$ & Unmatched & 1.627 & 0.293 & 1.334 & 0.204 & 6.54 & $* *$ \\
\hline & & Matched & 1.627 & 0.220 & 1.407 & 0.627 & 2.24 & $* *$ \\
\hline \multirow[t]{2}{*}{ dlnEXPORTS } & $\mathrm{t}+3$ & Unmatched & 1.668 & 0.317 & 1.351 & 0.219 & 6.17 & $* *$ \\
\hline & & Matched & 1.668 & -0.050 & 1.718 & 0.663 & 2.59 & $* *$ \\
\hline
\end{tabular}

Notes: Treated and Controls denote averages for FDI initiators and non-MNEs, respectively. Treated and Controls denote the change from $t-2$ in the log of variables. The number of treated firms is 56 . The common support condition is imposed. $* *$ and $*$ indicate significance at $5 \%$ and $10 \%$, respectively.

of temporary workers, although it contradicts the baseline results in columns (1)-(3) in Table 回.

The coefficients of dlnCI are negative in columns (1)-(6) and are significant in columns (1), (4), and (6). This phenomenon indicates that firms with higher capital intensity growth hire permanent rather than temporary workers, suggesting that escalating degrees of capital intensity are compatible with permanent workers.

Similarly, the coefficients of $\operatorname{dn} V A$ turn negative in columns (1)-(6) and are significant in columns (1), (2), and (4)-(5). This finding suggests that firms with greater growth in value added reduce the share of temporary workers in the wage bill and in employment. Furthermore, the industry change dummy ( $\mathrm{d} I N D U S T R Y)$ becomes negative and significant in columns (2)-(6), suggesting that switching industries correlates negatively to the share of temporary workers.

In summary, DID estimation using the matched sample confirms that temporary workers initially are complementary to vertical FDI but that this complementary relationship does not persist. This section reveals that the main finding is robust although the signs of the coefficients of several explanatory variables change after matching. 
Table 9: Effects of FDI in Asia on ratios of temporary workers: DID using the matched sample

\begin{tabular}{|c|c|c|c|c|c|c|}
\hline & (1) & $\begin{array}{c}(2) \\
\text { ATEMPS }\end{array}$ & $\overline{(3)}$ & $\overline{(4)}$ & $\begin{array}{c}(5) \\
\text { dTEMPR }\end{array}$ & $(6)$ \\
\hline & $t+1$ & $\mathrm{t}+2$ & $t+3$ & $\mathrm{t}+1$ & $t+2$ & $\mathrm{t}+3$ \\
\hline FDI_START & $\begin{array}{c}3.481^{* * * *} \\
{[1.270]}\end{array}$ & $\begin{array}{c}3.168^{* *} \\
{[1.465]}\end{array}$ & $\begin{array}{c}0.691 \\
{[1.630]}\end{array}$ & $\begin{array}{l}3.429^{*} \\
{[1.750]}\end{array}$ & $\begin{array}{c}1.813 \\
{[2.130]}\end{array}$ & $\begin{array}{l}-2.291 \\
{[2.137]}\end{array}$ \\
\hline dlnWAGE & $\begin{array}{c}5.973 \\
{[3.963]}\end{array}$ & $\begin{array}{c}4.176 \\
{[3.558]}\end{array}$ & $\begin{array}{c}8.323^{* *} \\
{[3.348]}\end{array}$ & $\begin{array}{c}13.920^{* *} \\
{[5.360]}\end{array}$ & $\begin{array}{c}10.933^{* *} \\
{[4.932]}\end{array}$ & $\begin{array}{c}16.358^{* * *} \\
{[4.392]}\end{array}$ \\
\hline $\mathrm{d} \ln \mathrm{CI}$ & $\begin{array}{c}-8.396^{* *} \\
{[3.509]}\end{array}$ & $\begin{array}{l}-5.443 \\
{[4.869]}\end{array}$ & $\begin{array}{l}-2.498 \\
{[4.653]}\end{array}$ & $\begin{array}{c}-13.752^{* *} \\
{[5.300]}\end{array}$ & $\begin{array}{c}-11.693 \\
{[7.348]}\end{array}$ & $\begin{array}{c}-10.068^{*} \\
{[6.000]}\end{array}$ \\
\hline $\mathrm{d} \ln \mathrm{VA}$ & $\begin{array}{c}-9.696^{* * *} \\
{[2.414]}\end{array}$ & $\begin{array}{c}-4.735^{* *} \\
{[2.307]}\end{array}$ & $\begin{array}{l}-3.070 \\
{[2.293]}\end{array}$ & $\begin{array}{c}-14.826^{* * *} \\
{[3.797]}\end{array}$ & $\begin{array}{c}-7.338^{*} \\
{[3.727]}\end{array}$ & $\begin{array}{l}-4.352 \\
{[3.525]}\end{array}$ \\
\hline dINDUSTRY & $\begin{array}{l}-2.200 \\
{[2.714]}\end{array}$ & $\begin{array}{c}-6.017^{* * *} \\
{[1.633]}\end{array}$ & $\begin{array}{c}-6.140^{*} \\
{[3.250]}\end{array}$ & $\begin{array}{c}-7.393^{* *} \\
{[3.720]}\end{array}$ & $\begin{array}{c}-12.716^{* * *} \\
{[3.205]}\end{array}$ & $\begin{array}{c}-11.346^{* *} \\
{[4.488]}\end{array}$ \\
\hline Observations & 112 & 112 & 112 & 112 & 112 & 112 \\
\hline $\mathrm{R}$-squared & 0.186 & 0.144 & 0.107 & 0.245 & 0.235 & 0.250 \\
\hline
\end{tabular}

Notes: Standard errors are in brackets. Constants are suppressed. ***, **, and * indicate significance at $1 \%$, $5 \%$, and $10 \%$, respectively.

\section{Robustness checks}

\subsection{All FDI initiators}

The previous sections employed FDI in Asia as a measure of vertical FDI. However, Alfaro and Charlton (200.9) and Baldwin and (Okubo (2014) suggest that vertical FDI is far more prevalent than previously thought and that multinational firms' activities in host countries are too complex to distinguish vertical FDI from horizontal FDI. I therefore conducted the estimation using the sample of all FDI initiators and all non-MNEs to check robustness of the main results.

The number of FDI initiators rose from 68 to 94 on including firms that initiated FDI outside Asia (e.g., North America and Europe) and firms that initiated FDI in multiple regions. Estimation results using the matched sample are in Table $\mathbf{0}$. The results resemble those in Table $\mathbf{9}$. They indicate that FDI initiators raise the share of temporary workers more than non-MNEs during the initial stages of FDI, but the complementarity between FDI and employing temporary workers vanishes in subsequent years.

\subsection{Dispatched workers}

As shown in Tables $\square$ and 2 , the share of dispatched workers rose rapidly in Japan's machinery industry during 2001-2007, whereas the shares of part-time workers and day laborers 
Table 10: Effects of FDI in Asia and other regions on the ratio of temporary workers: DID using the matched sample

\begin{tabular}{|c|c|c|c|c|c|c|}
\hline & \multicolumn{3}{|c|}{ dTEMPS } & \multicolumn{3}{|c|}{ dTEMPR } \\
\hline & $t+1$ & $\mathrm{t}+2$ & $t+3$ & $t+1$ & $t+2$ & $\mathrm{t}+3$ \\
\hline FDI_START & $\begin{array}{c}3.445^{* * *} \\
{[1.112]}\end{array}$ & $\begin{array}{c}3.332^{* *} \\
{[1.330]}\end{array}$ & $\begin{array}{l}-0.184 \\
{[1.529]}\end{array}$ & $\begin{array}{c}3.862^{* *} \\
{[1.582]}\end{array}$ & $\begin{array}{c}2.277 \\
{[1.979]}\end{array}$ & $\begin{array}{l}-2.608 \\
{[2.018]}\end{array}$ \\
\hline dlnWAGE & $\begin{array}{c}4.748 \\
{[3.414]}\end{array}$ & $\begin{array}{c}0.258 \\
{[3.052]}\end{array}$ & $\begin{array}{c}-8.138^{* * *} \\
{[1.766]}\end{array}$ & $\begin{array}{c}12.473^{* * *} \\
{[4.706]}\end{array}$ & $\begin{array}{c}5.926 \\
{[3.999]}\end{array}$ & $\begin{array}{c}1.029 \\
{[1.568]}\end{array}$ \\
\hline $\mathrm{d} \ln C I$ & $\begin{array}{c}-9.773^{* * *} \\
{[3.306]}\end{array}$ & $\begin{array}{l}-6.118 \\
{[4.436]}\end{array}$ & $\begin{array}{l}-0.943 \\
{[4.642]}\end{array}$ & $\begin{array}{c}-16.504^{* * *} \\
{[5.230]}\end{array}$ & $\begin{array}{c}-13.237^{*} \\
{[6.724]}\end{array}$ & $\begin{array}{l}-8.701 \\
{[5.992]}\end{array}$ \\
\hline$d \ln V A$ & $\begin{array}{c}-8.749^{* * *} \\
{[2.019]}\end{array}$ & $\begin{array}{c}-3.829^{* *} \\
{[1.703]}\end{array}$ & $\begin{array}{c}2.461 \\
{[2.225]}\end{array}$ & $\begin{array}{c}-14.185^{* * *} \\
{[3.360]}\end{array}$ & $\begin{array}{c}-5.794^{* *} \\
{[2.721]}\end{array}$ & $\begin{array}{l}-0.065 \\
{[3.058]}\end{array}$ \\
\hline dINDUSTRY & $\begin{array}{l}-1.822 \\
{[2.180]}\end{array}$ & $\begin{array}{c}-5.144^{* * *} \\
{[1.501]}\end{array}$ & $\begin{array}{l}-3.970 \\
{[3.760]}\end{array}$ & $\begin{array}{c}-6.454^{* *} \\
{[3.043]}\end{array}$ & $\begin{array}{c}-11.463^{* * *} \\
{[2.833]}\end{array}$ & $\begin{array}{c}-9.250^{*} \\
{[4.882]}\end{array}$ \\
\hline Observations & 148 & 148 & 148 & 148 & 148 & 148 \\
\hline R-squared & 0.165 & 0.121 & 0.306 & 0.230 & 0.187 & 0.126 \\
\hline
\end{tabular}

Notes: Standard errors are in brackets. Constants are suppressed. ***, **, and * indicate significance at $1 \%$, $5 \%$, and $10 \%$, respectively.

remained generally stable. This subsection, therefore, examines how initiating FDI in Asia affected the share of dispatched workers using the matched sample.

Table $\square$ presents the estimation results using the wage and employment shares of dispatched workers (DISPS and DISPR) instead of those for all temporary workers. The results resemble the main results in Table $\mathbb{Q}$ although the positive coefficient of the dummy for FDI initiators becomes significant in column (5) of Table $\mathbb{}$. The complementary relationship between FDI and dispatched workers lasts two years after initiating FDI but vanishes after that. The analysis in this subsection, therefore, confirms the main results.

\subsection{Post crisis period}

The previous section examines the period 2001-2007, which excludes the years after the 2008 financial crisis. This subsection concerns DID estimations for 2003-2013. This timespan includes the post-crisis period and features six new cohorts shown in Table ए2.

Table [3] presents the DID estimation results using the matched sample for 2003-2013. ${ }^{[0.9}$ The coefficients of FDI initiators become insignificant in all columns, suggesting no difference between FDI initiators and non-MNEs in their employment of temporary workers during this period. The complementarity between initiating FDI and employing temporary workers

\footnotetext{
${ }^{* 9}$ I present estimation results without seven outliers and its matched firms. However, estimation results with the outliers also confirm the main findings that initiating FDI yields no persistent effect on the share of temporary workers. I also confirm the results using the unmatched sample.
} 
Table 11: Effects of FDI in Asia on the dispatched worker ratio: DID using the matched sample

\begin{tabular}{|c|c|c|c|c|c|c|}
\hline & $\overline{(\overline{(1)}}$ & $\begin{array}{c}(2) \\
\text { dDISPS }\end{array}$ & $\overline{(3)}$ & $\overline{~(4)}$ & $\begin{array}{c}(5) \\
\text { dDISPR }\end{array}$ & $\overline{(6)}$ \\
\hline & $\mathrm{t}+1$ & $\mathrm{t}+2$ & $\mathrm{t}+3$ & $t+1$ & $\mathrm{t}+2$ & $\mathrm{t}+3$ \\
\hline FDI_START & $\begin{array}{c}3.861^{* * *} \\
{[1.291]}\end{array}$ & $\begin{array}{c}4.150^{* * * *} \\
{[1.429]}\end{array}$ & $\begin{array}{c}1.731 \\
{[1.705]}\end{array}$ & $\begin{array}{c}4.749^{* *} \\
{[1.822]}\end{array}$ & $\begin{array}{c}4.676^{* *} \\
{[1.933]}\end{array}$ & $\begin{array}{c}0.916 \\
{[2.247]}\end{array}$ \\
\hline dlnWAGE & $\begin{array}{c}7.419 * * \\
{[3.584]}\end{array}$ & $\begin{array}{c}3.738 \\
{[3.586]}\end{array}$ & $\begin{array}{c}8.067^{* *} \\
{[3.481]}\end{array}$ & $\begin{array}{c}13.023^{* *} \\
{[5.185]}\end{array}$ & $\begin{array}{c}7.936 \\
{[4.815]}\end{array}$ & $\begin{array}{c}13.026^{* * *} \\
{[4.588]}\end{array}$ \\
\hline $\mathrm{d} \ln C I$ & $\begin{array}{c}-9.466^{* * *} \\
{[3.237]}\end{array}$ & $\begin{array}{l}-3.572 \\
{[5.167]}\end{array}$ & $\begin{array}{l}-0.646 \\
{[5.105]}\end{array}$ & $\begin{array}{c}-12.899 * * * \\
{[4.791]}\end{array}$ & $\begin{array}{l}-7.083 \\
{[6.967]}\end{array}$ & $\begin{array}{l}-2.287 \\
{[6.654]}\end{array}$ \\
\hline$d \ln V A$ & $\begin{array}{c}-8.981^{* * *} \\
{[2.217]}\end{array}$ & $\begin{array}{c}-3.662^{*} \\
{[2.082]}\end{array}$ & $\begin{array}{l}-2.746 \\
{[2.353]}\end{array}$ & $\begin{array}{c}-12.145^{* * *} \\
{[3.097]}\end{array}$ & $\begin{array}{l}-4.486 \\
{[2.785]}\end{array}$ & $\begin{array}{l}-2.993 \\
{[3.133]}\end{array}$ \\
\hline dINDUSTRY & $\begin{array}{c}0.785 \\
{[2.625]}\end{array}$ & $\begin{array}{c}-2.571^{*} \\
{[1.544]}\end{array}$ & $\begin{array}{l}-4.205 \\
{[2.910]}\end{array}$ & $\begin{array}{c}0.174 \\
{[3.593]}\end{array}$ & $\begin{array}{c}-4.549^{* *} \\
{[1.926]}\end{array}$ & $\begin{array}{c}-6.934^{*} \\
{[3.785]}\end{array}$ \\
\hline Observations & 112 & 112 & 112 & 112 & 112 & 112 \\
\hline R-squared & 0.176 & 0.107 & 0.082 & 0.183 & 0.136 & 0.129 \\
\hline
\end{tabular}

Notes: Standard errors are in brackets. Constants are suppressed. ***, **, and * indicate significance at $1 \%$, $5 \%$, and $10 \%$, respectively.

Table 12: Alternative cohort of FDI initiators and non-MNEs

\begin{tabular}{ccccccc}
\hline & Cohort 1 & Cohort 2 & Cohort 3 & Cohort 4 & Cohort 5 & Cohort 6 \\
\hline$t-2$ & 2003 & 2004 & 2005 & 2006 & 2007 & 2008 \\
$t-1$ & 2004 & 2005 & 2006 & 2007 & 2008 & 2009 \\
$t$ & $\mathbf{2 0 0 5}$ & $\mathbf{2 0 0 6}$ & $\mathbf{2 0 0 7}$ & $\mathbf{2 0 0 8}$ & $\mathbf{2 0 0 9}$ & $\mathbf{2 0 1 0}$ \\
$t+1$ & 2006 & 2007 & 2008 & 2009 & 2010 & 2011 \\
$t+2$ & 2007 & 2008 & 2009 & 2010 & 2011 & 2012 \\
$t+3$ & 2008 & 2009 & 2010 & 2011 & 2012 & 2013 \\
\hline
\end{tabular}


during its early stages vanishes. However, the results in this subsection again confirm that initiating FDI yields no persistent effect on the share of temporary workers.

Table 13: Effects of FDI in Asia on the ratio of temporary workers in the post-crisis period: DID using the matched sample

\begin{tabular}{|c|c|c|c|c|c|c|}
\hline & (1) & dTEMPS & $(3)$ & \multicolumn{2}{|c|}{ dTEMPR } & (6) \\
\hline & $t+1$ & $t+2$ & $t+3$ & $t+1$ & $t+2$ & $\mathrm{t}+3$ \\
\hline FDI_START & $\begin{array}{l}-0.664 \\
{[1.385]}\end{array}$ & $\begin{array}{l}-0.938 \\
{[1.529]}\end{array}$ & $\begin{array}{c}-0.824 \\
{[1.424]}\end{array}$ & $\begin{array}{l}-0.513 \\
{[1.640]}\end{array}$ & $\begin{array}{c}-1.033 \\
{[1.763]}\end{array}$ & $\begin{array}{c}-0.754 \\
{[1.691]}\end{array}$ \\
\hline dlnWAGE & $\begin{array}{l}-0.270 \\
{[0.886]}\end{array}$ & $\begin{array}{l}-0.253 \\
{[0.914]}\end{array}$ & $\begin{array}{l}-0.220 \\
{[0.872]}\end{array}$ & $\begin{array}{c}1.364 \\
{[1.087]}\end{array}$ & $\begin{array}{c}1.330 \\
{[1.227]}\end{array}$ & $\begin{array}{c}1.166 \\
{[0.967]}\end{array}$ \\
\hline $\mathrm{d} \ln \mathrm{CI}$ & $\begin{array}{c}3.561 \\
{[5.528]}\end{array}$ & $\begin{array}{c}2.345 \\
{[4.301]}\end{array}$ & $\begin{array}{c}9.754^{* *} \\
{[3.780]}\end{array}$ & $\begin{array}{c}3.000 \\
{[6.071]}\end{array}$ & $\begin{array}{l}-2.906 \\
{[5.876]}\end{array}$ & $\begin{array}{c}6.196 \\
{[4.211]}\end{array}$ \\
\hline dlnVA & $\begin{array}{l}-0.164 \\
{[1.380]}\end{array}$ & $\begin{array}{l}-1.160 \\
{[1.928]}\end{array}$ & $\begin{array}{c}1.946 \\
{[1.503]}\end{array}$ & $\begin{array}{c}0.683 \\
{[1.927]}\end{array}$ & $\begin{array}{l}-1.606 \\
{[2.517]}\end{array}$ & $\begin{array}{l}3.899^{*} \\
{[2.096]}\end{array}$ \\
\hline dINDUSTRY & $\begin{array}{c}-4.879^{*} \\
{[2.633]}\end{array}$ & $\begin{array}{l}-1.216 \\
{[3.147]}\end{array}$ & $\begin{array}{c}1.421 \\
{[2.289]}\end{array}$ & $\begin{array}{c}-8.757^{* *} \\
{[3.752]}\end{array}$ & $\begin{array}{l}-0.152 \\
{[3.659]}\end{array}$ & $\begin{array}{c}6.249^{* *} \\
{[2.786]}\end{array}$ \\
\hline Observations & 228 & 228 & 228 & 228 & 228 & 228 \\
\hline R-squared & 0.086 & 0.098 & 0.066 & 0.177 & 0.145 & 0.087 \\
\hline
\end{tabular}

Notes: Standard errors are in brackets. Constants are suppressed. ***, **, and * indicate significance at $1 \%$, $5 \%$, and $10 \%$, respectively.

\section{Conclusion}

Little is known about why the ratio of temporary workers has risen in recent years (Asano et an, 2013). To fill that gap in the literature, this study investigates the relationship between globalization in the form of offshoring and employment and wage shares of temporary workers using firm-level data from Japanese manufacturers for 2001-2007. It employes firstdifferenced DID estimation with PSM to address potential endogeneity. In particular, this study estimates the causal effects of FDI in Asia on the wage and employment shares of temporary workers and re-examines the hypothesis that offshoring substitutes for employing temporary workers.

This study finds that there are positive effects of vertical FDI on the wage and employment share of temporary workers one year after starting FDI but they vanish in subsequent years. Therefore, this study concludes that the relationship between temporary workers and vertical FDI is complementary in the early stage of FDI and that no persistent effect of vertical FDI occurs.

To estimate the pure effects of vertical FDI, this study focuses on firms that start vertical FDI and employs the first-differenced DID approach, together with the PSM technique. 
Therefore, this study does not consider how existing MNEs' offshoring activities affect their wage and employment share of temporary workers. In this sense, the analysis in this study is partial, and future studies are required to investigate existing MNEs' offshoring activities.

Growth in temporary workers might result in greater income inequality because temporary workers' wages are lower and their jobs are more tenuous than those of permanent workers. In fact, the Japanese government regards the growth in temporary workers as a major cause of rising income inequality. ${ }^{\circledR 0}$ Offshoring might also result in widening income inequality ${ }^{\circledR 17}$ by increasing the share of low-wage temporary workers. This study finds no evidence that FDI in Asia induces firms to increase the employment share of temporary workers. Therefore, this study finds little evidence for the contention that vertical FDI results in greater income inequality and greater job insecurity through increasing the share of temporary workers.

\section{Acknowledgments}

I gratefully acknowledge the financial support from the Japan Society for the Promotion of Science's Grants-in-Aid for Scientific Research (No. 24730234; 15K17063). I thank Masahiro Endoh for his invaluable suggestions. I also thank Naoto Jinji and other seminar participants for their helpful comments. I am grateful to the Ministry of Economy, Trade and Industry for providing the micro data of the Basic Survey of Japanese Business Structure and Activities employed in this study.

\footnotetext{
${ }^{*}{ }^{10}$ See Annual Report on the Japanese Economy and Public Finance 2009 by Cabinet Office, Government of Japan and The White Paper on Labour and Economy 2012 by Japanese Ministry of Health, Labour and Welfare.

${ }^{*} 11$ This study is related to previous studies that examined whether offshoring exacerbates inequality through a widening of the wage differential between temporary and permanent workers. Using German data, Gorg and Görlich (2012) found no systematic differences between temporary and permanent workers with respect to the effects of offshoring for wages although they found that offshoring increases the unemployment risk more for temporary than for permanent workers. Lee and Lee (2013) used South Korean data to reveal that the positive impact of offshoring on wages is significantly weaker for temporary workers than for permanent workers.
} 


\section{References}

Alfaro, L. And A. Charlton (2009): "Intra-industry Foreign Direct Investment," American Economic Review, 99, 2096-2119.

Asano, H., T. Ito, And D. Kawaguchi (2013): "Why Has the Fraction of Nonstandard Workers Increased? A Case Study of Japan," Scottish Journal of Political Economy, 60, $360-389$.

Baldwin, R. And T. Okubo (2014): "Networked FDI: Sales and Sourcing Patterns of Japanese Foreign Affiliates," The World Economy, 37, 1051-1080.

Berman, E., J. Bound, And S. Machin (1998): "Implications of Skill-Biased Technological Change: International Evidence," Quarterly Journal of Economics, 113, 1245-1279.

CRINò, R. (2010): "Employment Effects of Service Offshoring: Evidence from Matched Firms," Economics Letters, 107, 253-256.

Esteban-Pretel, J., R. Nakajima, and R. Tanaka (2011): "Are Contingent Jobs Dead Ends or Stepping Stones to Regular Jobs? Evidence from a Structural Estimation," Labour Economics, 18, 513-526.

GörG, H. AND D. Görlich (2012): "Offshoring, Wages and Job Security of Temporary Workers," Review of World Economics, 151, 1-22.

HeAd, K. AND J. RiEs (2002): "Offshore Production and Skill Upgrading by Japanese Manufacturing Firms," Journal of International Economics, 58, 81-105.

Helpman, E., M. J. Melitz, and S. R. Yeaple (2004): "Export versus FDI with Heterogeneous Firms," American Economic Review, 94, 300-316.

Hijzen, A., S. Jean, And T. Mayer (2011): "The Effects at Home of Initiating Production Abroad: Evidence from Matched French Firms," Review of World Economics, 147, 457483.

Kimura, F. And K. Kiyota (2006): "Exports, FDI, and Productivity: Dynamic Evidence from Japanese Firms," Review of World Economics, 142, 695-719.

LeE, H. And J. LeE (2013): "The Impact of Offshoring on Temporary Workers: Evidence on Wages from South Korea," Review of World Economics, 151, 1-33.

Levinsohn, J. And A. Petrin (2003): "Estimating Production Functions using Inputs to Control for Unobservables," The Review of Economic Studies, 70, 317-341. 
Nishimura, K. G., T. Nakajima, And K. Kiyota (2005): "Does the Natural Selection Mechanism Still Work in Severe Recessions?: Examination of the Japanese Economy in the 1990s," Journal of Economic Behavior $\&$ Organization, 58, 53-78.

Okudaira, H., F. Ohtake, K. Kume, and K. Tsuru (2013): "What Does a Temporary Help Service Job Offer? Empirical Suggestions from a Japanese Survey," Journal of the Japanese and International Economies, 28, 37-68.

Presbitero, A. F., M. G. Richiardi, And A. A. Amighini (2015): "Is Labor Flexibility a Substitute to Offshoring? Evidence from Italian Manufacturing," International Economics, $142,81-93$. 


\section{Appendix}

Table 14: Descriptive statistics for the DID estimation using an unmatched sample

\begin{tabular}{lrrrrr}
\hline variable & $\mathbf{N}$ & $\mathbf{m i n}$ & mean & max & sd \\
\hline dTEMPR_f1 & 4,076 & -84.783 & 2.875 & 60.867 & 11.297 \\
dTEMPS_f1 & 4,076 & -98.344 & 12.804 & 99.574 & 38.210 \\
FDI_START & 4,076 & 0.000 & 0.017 & 1.000 & 0.128 \\
dlnWAGE_f1 & 4,076 & -8.752 & 0.198 & 8.733 & 0.588 \\
dlnCI_f1 & 4,076 & -3.282 & -0.038 & 3.078 & 0.263 \\
dlnVA_f1 & 4,076 & -5.250 & 0.334 & 7.926 & 0.522 \\
dINDUSTRY_f1 & 4,076 & 0.000 & 0.065 & 1.000 & 0.247 \\
year & 4,076 & $2,003.000$ & $2,003.500$ & $2,004.000$ & 0.500 \\
& & & & & \\
dTEMPR_f2 & 4,076 & -84.783 & 4.375 & 63.116 & 12.480 \\
dTEMPS_f2 & 4,076 & -99.225 & 17.234 & 99.953 & 40.383 \\
FDI_START & 4,076 & 0.000 & 0.017 & 1.000 & 0.128 \\
dlnWAGE_f2 & 4,076 & -8.397 & 0.245 & 8.465 & 0.537 \\
dlnCI_f2 & 4,076 & -3.870 & -0.053 & 2.214 & 0.275 \\
dlnVA_f2 & 4,076 & -4.618 & 0.460 & 8.031 & 0.565 \\
dINDUSTRY_f2 & 4,076 & 0.000 & 0.067 & 1.000 & 0.250 \\
year & 4,076 & $2,003.000$ & $2,003.500$ & $2,004.000$ & 0.500 \\
& & & & & \\
dTEMPR_f3 & 4,076 & -67.960 & 5.889 & 73.862 & 13.440 \\
dTEMPS_f3 & 4,076 & -98.990 & 20.821 & 99.953 & 42.660 \\
FDI_START & 4,076 & 0.000 & 0.017 & 1.000 & 0.128 \\
dlnWAGE_f3 & 4,076 & -8.397 & 0.274 & 8.525 & 0.625 \\
dlnCI_f3 & 4,076 & -3.092 & -0.069 & 2.802 & 0.284 \\
dlnVA_f3 & 4,076 & -6.441 & 0.580 & 8.188 & 0.607 \\
dINDUSTRY_f3 & 4,076 & 0.000 & 0.075 & 1.000 & 0.263 \\
year & 4,076 & $2,003.000$ & $2,003.500$ & $2,004.000$ & 0.500 \\
\hline
\end{tabular}


Table 15: Descriptive statistics for the DID estimation using a matched sample

\begin{tabular}{lrrrrr}
\hline variable & $\mathbf{N}$ & min & mean & max & sd \\
\hline dTEMPR_f1 & 112 & -15.842 & 6.023 & 39.704 & 9.246 \\
dTEMPS_f1 & 112 & -13.034 & 22.206 & 97.094 & 32.161 \\
FDI_START & 112 & 0.000 & 0.500 & 1.000 & 0.502 \\
dlnWAGE_f1 & 112 & -0.530 & 0.174 & 1.173 & 0.271 \\
dlnCI_f1 & 112 & -0.758 & -0.089 & 1.015 & 0.184 \\
dlnVA_f1 & 112 & -0.442 & 0.365 & 1.829 & 0.360 \\
dINDUSTRY_f1 & 112 & 0.000 & 0.098 & 1.000 & 0.299 \\
year & 112 & $2,003.000$ & $2,003.482$ & $2,004.000$ & 0.502 \\
& & & & & \\
dTEMPR_f2 & 112 & -30.506 & 6.506 & 35.831 & 10.360 \\
dTEMPS_f2 & 112 & -70.328 & 26.047 & 96.741 & 36.585 \\
FDI_START & 112 & 0.000 & 0.500 & 1.000 & 0.502 \\
dlnWAGE_f2 & 112 & -0.682 & 0.183 & 1.166 & 0.292 \\
dlnCI_f2 & 112 & -0.841 & -0.084 & 1.011 & 0.192 \\
dlnVA_f2 & 112 & -0.259 & 0.448 & 1.955 & 0.376 \\
dINDUSTRY_f2 & 112 & 0.000 & 0.107 & 1.000 & 0.311 \\
year & 112 & $2,003.000$ & $2,003.482$ & $2,004.000$ & 0.502 \\
& & & & & \\
dTEMPR_f3 & 112 & -43.006 & 9.178 & 51.365 & 12.371 \\
dTEMPS_f3 & 112 & -90.961 & 32.800 & 98.398 & 40.561 \\
FDI_START & 112 & 0.000 & 0.500 & 1.000 & 0.502 \\
dlnWAGE_f3 & 112 & -0.544 & 0.234 & 1.044 & 0.304 \\
dlnCI_f3 & 112 & -0.801 & -0.130 & 0.333 & 0.190 \\
dlnVA_f3 & 112 & -0.143 & 0.569 & 1.863 & 0.390 \\
dINDUSTRY_f3 & 112 & 0.000 & 0.134 & 1.000 & 0.342 \\
year & 112 & $2,003.000$ & $2,003.482$ & $2,004.000$ & 0.502 \\
\hline
\end{tabular}

